\title{
Soil Organic Carbon and Nitrogen Stocks Following Land Use Changes in a Sub-Humid Climate
}

\author{
Birhanu Biazin ${ }^{1,2}$, Dong-Gill Kim ${ }^{2} \&$ Tefera Mengistu ${ }^{3}$ \\ ${ }^{1}$ International Potato Center (CIP), C/O, ILRI, P.O. Box, 5689, Addis Ababa, Ethiopia \\ ${ }^{2}$ Hawassa University, Wondo Genet College of Forestry and Natural Resources, Shashemene, Ethiopia \\ ${ }^{3}$ Ministry of Environment, Forest and Climate Change, PO. Box 12760; Addis Ababa, Ethiopia \\ Correspondence: Birhanu Biazin, International Potato Center (CIP), C/O, ILRI,P.O. Box, 5689, Addis Ababa, \\ Ethiopia. Tel: 251-462-125-058. E-mail: birhanubiazin@gmail.com
}

Received: October 10, 2017

Accepted: October 24, 2017

Online Published: February 5, 2018

doi:10.5539/enrr.v8n1p70

URL: https://doi.org/10.5539/enrr.v8n1p70

\begin{abstract}
There has been an incessant conversion of natural forests to agricultural land uses such as farmlands, grasslands and parkland agro-forestry in Africa during the last century. This study investigated changes in soil organic carbon (SOC) and total nitrogen (TN) stocks following the conversion of a natural forest to coffee-based agro-forestry, grazing grassland and well-managed maize farm in a sub-humid tropical climate of Ethiopia. Soil samples (up to $1 \mathrm{~m}$ depth) were taken from each of these four land use types. Taking the natural forest as a baseline and with duration of 35 years since land use conversion, the total SOC and TN stocks were not significantly different $(P>0.05)$ among the different land use types when the entire $1 \mathrm{~m}$ soil depth was considered. However, in the upper $0-10 \mathrm{~cm}$ soil depth, the SOC and TN stocks were significantly higher $(P<0.05)$ in the natural forest than the agricultural land use types. There were different patterns of SOC and TN distributions along the soil depths for the different land use types. The SOC stocks decreased with depth in natural forest, but did not show any increasing or decreasing trends in maize farm, grazing grassland, and coffee-based agroforestry. The results of this study revealed that the negative effects of converting natural forests to agricultural land use types on SOC and TN can be prevented through appropriate land management practices in cultivated and grazing lands and use of proper agroforestry practices in a sub-humid tropical climate.
\end{abstract}

Key-words: Ethiopia; Land management; Soil depth; Land use; Agroforestry

\section{Introduction}

About six million $\mathrm{km}^{2}$ of forests have been converted to farmlands worldwide since 1850 (Lambin et al., 2003; de Souza et al., 2013; Kalema et al., 2014; Konig et al., 2014; Bruun et al., 2015). In Africa, native vegetation including woodlands and grasslands have increasingly been converted to farmlands (Diouf \& Lambin, 2001; Millennium Ecosystem Assessment, 2005). Similarly, there has been a continuous conversion of forests to farmlands in Ethiopia since the 1970's (Reusing, 2000; Tadesse, 2001; Biazin \& Sterk, 2013). Since the last four decades, the expansion of crop lands has gone to marginal lands of the Ethiopian highlands that are prone to land degradation (Zeleke \& Hurni, 2001; Moges \& Holden, 2009; Gebrehiwot et al., 2010; Biazin \& Sterk, 2013). The annual rate of deforestation in Ethiopia is $1.1 \%$ of the remaining forest area (FAO, 2010).

Tropical soils are important carbon pools as they hold 36-60\% of carbon in soil ecosystems (Malhi et al., 1999; Yimer et al., 2007; Don et al., 2011). Particularly, soils of high altitude tropical ecosystems are crucial in the global terrestrial carbon cycle as they have large stock as well as a potential candidate for carbon-based greenhouse gas emission, especially from peat soils (Sihi et al. 2016b, 2017b) which could be sensitive to climate change (Post et al., 2009; Yang et al., 2010). According to Don et al (2011), the highest losses of soil organic carbon (SOC) in the tropics were caused by conversion of forests into croplands $(-25 \%)$ and perennial crops $(-30 \%)$. This is mainly attributed to the decrease in organic matter inputs to the soil consistent with deforestation and the increased decomposition and erosion caused by soil disturbance in cultivated soils (Murty et al., 2002; MacLauchlan, 2006).

The effect of land use and land cover (LULC) changes from forests to agricultural land use types such as grasslands, pasture, agro-forestry and croplands on SOC showed no constant trends around the world (Guo \& Gifford, 2002; Murty et al., 2002; Don et al., 2011; Mohawesh et al., 2015; Yu et al., 2015). A meta-analysis by Guo and Gifford 
(2002) indicated that the SOC stocks increased by $8 \%$ following the conversion of forests to grasslands. However, another meta-analysis by Don et al. (2011) indicated that the SOC stocks decreased by $12 \%$ followingconversion of forests into grasslands. A review by Murty et al. (2002) revealed that there were no consistent changes in soil carbon following conversion of forests to unmanaged pasture. According to Conant et al. (2001), there could be sequestration of atmospheric carbon following land use conversion from either native vegetation or cropland to grassland depending on the type of management. Therefore, lack of constant trends on soil carbon dynamics following the conversion of forests to grasslands and pasture suggests that site-specific studies are required to understand the trends in SOC and TN stocks under a given agro-climatic and management conditions.

Although Africa is one of the current hotspots of LULC changes and degradation of native vegetation, there has been insufficient data to examine the consequent effects on SOC and total nitrogen (TN) dynamics including changes along the vertical soil profile (Don et al., 2011). Such lack of adequate information on the effect of LULC changes on SOC and TN dynamics may hamper the sustainable management and use of the soil resources in tropical ecosystems. The remnant native vegetation in southern Ethiopia has been constantly converted to crop and grazing grasslands, and coffee-based agro-forestry (Dessie \& Kleman, 2007; Garedew et al., 2009; Moges \& Holden, 2009). However, there have been meager studies that examined the impacts of converting natural forests to well-managed agricultural land uses on SOC and TN dynamics in Ethiopia. The knowledge about the effect of converting natural forests to traditional agroforestry on SOC and TN stocks are generally limited (Demessie et al., 2013). Most global studies on soil carbon dynamics focused on the top $30-40 \mathrm{~cm}$ soil depths while the carbon dynamics in the deeper soil layers are less studied (Meersmans et al., 2009; Yang, 2010). Hence, further studies are required to examine changes of SOC and TN stocks at lower depths and examine the redistribution in the soil profile following conversion of natural forests to other land use types.

The objective of the study was, therefore, to investigate the long-term effect of converting natural forests to agricultural land use types on SOC and TN stocks and their vertical distribution in the soil profile under a subhumid tropical climate of Southern Ethiopia. It was hypothesized that conversion of natural forests to agricultural land use types could reduce soil organic carbon and total nitrogen stocks in about four decades. Therefore, in this study, the SOC and TN stocks were compared between agricultural land use types and an adjacent natural forest from which they were converted. The study also examined the redistribution of soil organic carbon and total nitrogen stocks among the different soil depths following the conversion of natural forests to well managed agricultural lands use types.

\section{Materials and Methods}

\subsection{Site Descriptions}

The study was conducted in Wondo Genet area (around $7^{\circ} 06^{\prime} \mathrm{N}$ and $38^{\circ} 37^{\prime}$ E) at the eastern escarpment of the Central Rift Valley of Ethiopia (Figure 1). It is located about $260 \mathrm{~km}$ south of the capital city, Addis Ababa, and has an altitude of 1840-1980 meters above sea level. The study area has a sub-humid tropical climate with a mean annual rainfall of $950 \mathrm{~mm}$. The rainfall pattern is bi-modal, with short rainy season during March - May accounting for $34 \%$ of total rainfall, and long rainy season during June - October accounting for more than $55 \%$ of total rainfall (Figure 2). The remaining $11 \%$ of the annual rainfall occurs during November - February. However, it is highly variable between years both in terms of distribution during the months and total annual amounts. The mean monthly temperature is $20^{\circ} \mathrm{C}$ with mean monthly maximum and minimum values of $27^{\circ} \mathrm{C}$ and $13^{\circ} \mathrm{C}$, respectively (analyzed from long-term meteorological data of 1981-2010 at Wondo Genet College).

The bed rock in the area is mainly of basaltic composition, often overlaid by volcanic ash deposits from the late tertiary period (Anon, 1973). It is dominated with well-drained sandy loam and loam soils of high permeability and classified as MollicAndosols (FAO, 1988; Yimer, 2002). The top layer of the soil has a $\mathrm{pH}$ of 6.0 and Cation Exchange Capacity of 19.7-21.7 meq/(100 g soil) (Teklay, 2004). 


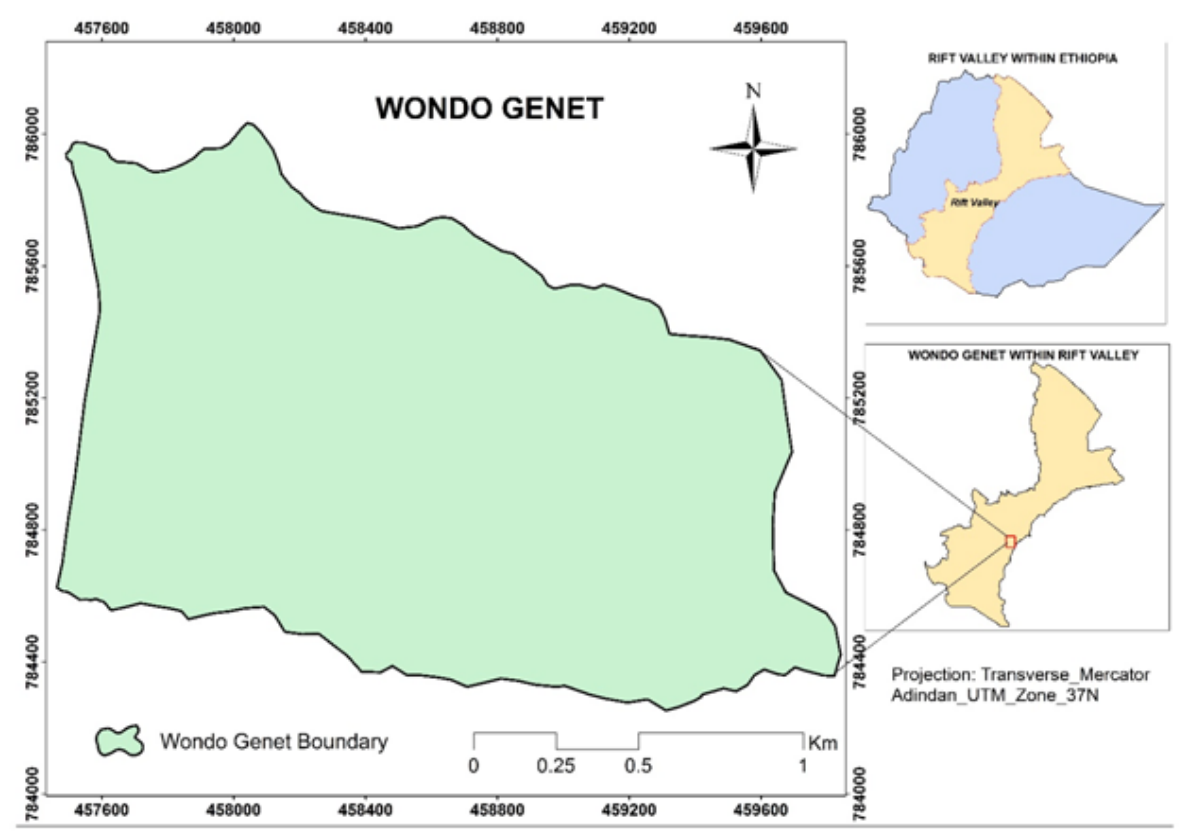

Figure 1. Site Descriptions

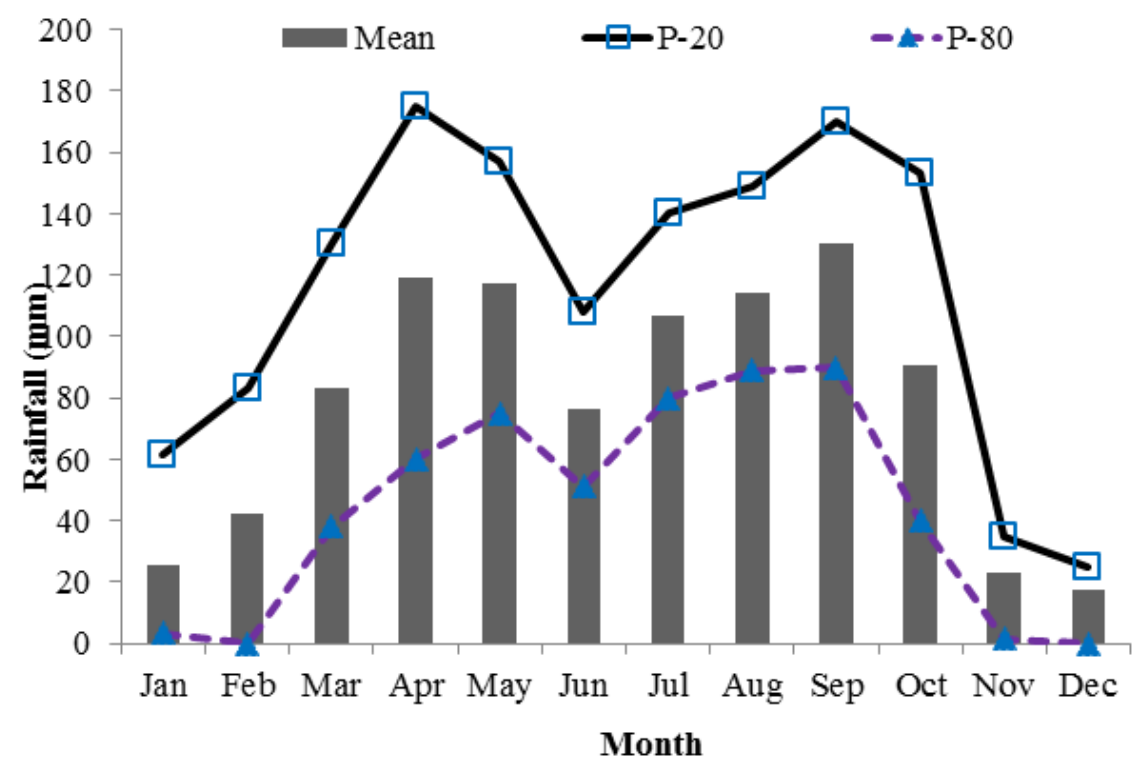

Figure 2. Long-term mean annual rainfall (Mean), 20\% probability of exceedance (P-20), and 80\% probability of exceedance (P-80) in Wondo Genet, Southern Ethiopia

\subsection{Description of the Studied Land-Use and Land Cover Types}

The study area has diversity of land use types within short distance separations. Four land-use and land cover (LULC) types encompassing natural forest (NF), coffee-based agroforestry (CAF), well-managed farmland (mostly used to grow maize, MF) and grazing grassland (GL) were considered in this study. The latter three landuses have been converted from the natural forest during 1964-1966 (Table 1). Since these lands are owned and managed by Wondo Genet College of Forestry and Natural Resources, Hawassa University, their history and management conditions have been well documented. They are located adjacent to each other with similar inherent soil properties. Hence, they offered the opportunity to study the variability and direction of changes in SOC and TN stocks following LULC changes. Table 1 summarizes the characteristics of the studied land-use and land cover types in the study area. 
Table 1. The characteristics of the different land-use and land cover types in Wondo Genet area of Southern Ethiopia

\begin{tabular}{|c|c|c|c|c|c|c|}
\hline $\begin{array}{l}\text { Land use or land } \\
\text { cover type }\end{array}$ & $\begin{array}{l}\text { Dominant tree and grass species } \\
\text { (except for the farmland) }\end{array}$ & $\begin{array}{l}\text { Year of } \\
\text { conversion from } \\
\text { native natural } \\
\text { forests }\end{array}$ & $\begin{array}{l}\text { Soil } \\
\text { type }\end{array}$ & $\begin{array}{l}\text { Dominant } \\
\text { texture class of } \\
\text { the surface soils }\end{array}$ & $\begin{array}{l}\text { Mean } \\
\text { elevation }\end{array}$ & Slope \\
\hline Natural forest & $\begin{array}{l}\text { Celtis africana trees mixed with } \\
\text { scattered Cordia africana, Millettia } \\
\text { ferruginea, Afrocarpus falcatus }\end{array}$ & - & Andosol & Sandy clay loam & 1920 & $7 \%$ \\
\hline $\begin{array}{l}\text { Coffee-based } \\
\text { agroforestry }\end{array}$ & $\begin{array}{l}\text { Cordia africana, Celtis africana, } \\
\text { Albizia gummifera and Millettia } \\
\text { ferruginea }\end{array}$ & 1964 & Andosol & $\begin{array}{l}\text { Sandy clay loam } \\
\text { to Clay loam }\end{array}$ & 1890 & $5 \%$ \\
\hline Grazing grassland & $\begin{array}{l}\text { Bermuda grass (Cynodon dactylon) } \\
\text { and Rhodes grass } \\
\text { (Andropogongayanus Kunth) }\end{array}$ & $1965-1966$ & Andosol & Sandy clay loam & 1905 & $5 \%$ \\
\hline $\begin{array}{l}\text { Well-managed } \\
\text { farmland } \\
\text { (dominantly maize } \\
\text { farm) }\end{array}$ & - & $1965-1966$ & Andosol & Sandy clay loam & 1910 & $5 \%$ \\
\hline
\end{tabular}

The NF is a type of montane forest that has been only slightly altered. It is dominated by Celtisafricana trees mixed with scattered Cordiaafricana, Millettiaferruginea, Afrocarpusfalcatus, and other shrubs. The CAFwas converted from the natural forest around 1964 through planting of the coffee (Coffea arabica L.) seedlings while selectively maintaining some shade trees. The dominant shade trees in the CAF include Cordia africana, Celtis africana, Millettia ferruginea and Albizia gummifera. The former two species constituted more than $60 \%$ of the shade trees in the CAF. Since its establishment, the coffee plants were pruned only in 2004. There has been intermittent spothoeing and slashing of the undergrowth weeds. It was managed similar to the traditional coffee-based agroforestry system owned by smallholder farmers in the southern part of the country.

The GL was converted from natural forest during 1965-1966. It has been used as a source of feed for the dairy cows owned by the College. The dominant indigenous grass species are Bermuda grass (Cynodon dactylon) and Rhodes grass (Andropogong ayanus Kunth). The grassland has been improved by over-sowing of legume forages like clover species and Desmodium (Desmodium uncinatum) to improve nitrogen-fixation and supplement protein sources for the dairy cows. However, there was no form of fertilizer applied on the GL. It has been used as a free grazing land and there were very few times when grasses were cut from the land for hay making. As compared to the traditional free grazing by the smallholder farmers, these grasslands have not been intensively grazed.

The MF was converted from the natural forest following clear-felling of the native tree species during 1965-1966. It has been used to grow teff (Eragratisteff) rotated with Maize (Zea mays) during the first 10 years after conversion. Thereafter, it has been used as Maize mono-cropping farmland. There were 1-2 disc-ploughing of the top $30 \mathrm{~cm}$ soil depth followed by one harrowing before sowing of maize every year. On average, $150 \mathrm{~kg} / \mathrm{ha}$ of Di-Ammonium Phosphate (DAP) and $75 \mathrm{~kg} / \mathrm{ha}$ of UREA fertilizers were applied on the farmland every year. This is equivalent to $62 \mathrm{~kg}$ Nitrogen per hectare per year. Pre-emergence and post-emergence removal of weeds was made using herbicides every year. Sometimes, the maize stalks were burnt in-situ immediately after each harvesting so as to prevent pest and weed prevalence. Much of the maize stover has been left to improve the soil fertility. The mean annual maize yield during the last ten years was 4 tons/ha which is much greater than the national average of 2.2 tons/ha (CSA, 2010).

\subsection{Soil Sampling and Analysis}

Soil samples were taken from five pits randomly located under each of the four LULC types. Soil samples were taken with a core sampler from 0-10, 10-20, 20-40, 40-60, 60-80 and 80-100 cm soil depths on the soil profile. These soil depths were purposively selected to compare the SOC and TN stocks at separate control sections (soil depths) and in the entire soil profile. First the pits were dug to $150 \mathrm{~cm}$ depth. Secondly, the soil depths were cleaned vertically and two soil core samples were taken from each depth by pushing the core sampler horizontally. Hence, a total of 240 soil samples were collected randomly from four LULC types at six soil depths ( 4 LULC types $\times 5$ pits $\times 6$ depths $\times$ 2 core samples per depth). The core sampler was a circular cylinder with a diameter of $5 \mathrm{~cm}$ and a height of $5 \mathrm{~cm}$. The first 120 core samples were unaltered and used to determine the soil bulk density. Soil bulk density was calculated 
by dividing the oven dry mass at $105^{\circ} \mathrm{C}$ by the volume of the core (Grossman \& Reinsch, 2002). The other 120 soil samples were altered as they were air-dried, mixed well for each depth and passed through a $2 \mathrm{~mm}$ sieve for analysis of SOC and TN. These sieved soils were used for analyses of SOC and TN stocks as there are no gravels in the predominantly loam soils of the study area (Wolka et al., 2015). The SOC concentration was determined according to the Walkley and Black method (Schnitzer, 1982). The TN was also analyzed using the Kjeldahal procedure (Bremner \& Mulvaney, 1982). The SOC and TN analyses were done at the laboratory of the International Livestock Research Institute (ILRI) in Addis Ababa, Ethiopia.

\subsection{Determination of Soil Organic Carbon and Nitrogen Stocks}

The soil organic carbon stocks $\left(\mathrm{g} \mathrm{m}^{-2}\right)$ for each sampled depth were calculated using the following equation.

$$
C=\left(z \times \rho_{b} \times c\right) \times 10
$$

Where,

$\mathrm{C}=$ carbon stock $\left(\mathrm{g} \mathrm{m}^{-2}\right)$ of a sample depth,

$\mathrm{z}=$ thickness of a sample depth $(\mathrm{cm})$,

$\rho_{\mathrm{b}}=$ bulk density $\left(\mathrm{g} \mathrm{cm}^{-3}\right)$ of a sample depth, and

$\mathrm{c}=$ carbon content $\left(\mathrm{g} \mathrm{kg}^{-1}\right.$ soil $)$ of a sample depth.

$10=$ the adjustment for the unit of carbon stock in to $\mathrm{g} \mathrm{m}^{-2}$

Similarly, soil $\mathrm{N}\left(\mathrm{g} \mathrm{m}^{-2}\right)$ stock for each sampled depth was calculated using the following equation:

$$
N=\left(z \times \rho_{b} \times n\right) \times 10
$$

Where,

$\mathrm{N}=$ nitrogen stock $\left(\mathrm{g} \mathrm{m}^{-2}\right)$ of a sample depth

$\mathrm{z}=$ thickness of a sample depth $(\mathrm{cm})$,

$\rho_{\mathrm{b}}=$ bulk density $\left(\mathrm{g} \mathrm{cm}^{-3}\right)$ of a sample depth, and

$\mathrm{n}=$ nitrogen content $\left(\mathrm{g} \mathrm{kg}^{-1}\right.$ soil) of a sample depth.

The final results of carbon and nitrogen stocks have been converted in to $\mathrm{Mg} \mathrm{ha}^{-1}$ by dividing the $\mathrm{g} \mathrm{m}^{-2}$ values by 100. Differences in soil bulk density between different LULC types affect comparisons of SOC and total nitrogen stocks by influencing the amount of soils that are sampled from a fixed soil depth (Mendham et al., 2002; Solomon et al., 2002). The changes in soil organic carbon as result of converting natural forests to agricultural land uses could be inflated by the differences in bulk density (Murty et al., 2002). For instance, long-term farming practices could alter the amount of organic matter incorporated, which directly influence the soil organic matter content per unit volume (Sihi et al., 2017a). These differences in soil bulk densities were considered by adjusting thickness of each sampled layer under each LULC with respect to equivalent weights of soils under the natural forest using the equation below.

$$
z_{\text {corr }}=\frac{\rho_{\text {forest }}}{\rho_{L U}} \times z
$$

Where,

$\mathrm{z}_{\mathrm{corr}}=\quad$ adjusted thickness of a sample soil layer under a given land use type,

$\rho_{\text {forest }}=$ bulk density of the sampled soil layer under the natural forest,

$\rho_{\mathrm{LU}}=\quad$ bulk density of the sampled soil layers under land use type,

$\mathrm{z}=\quad$ thickness of soil layers used during field sampling (Solomon et al., 2002).

Hence, the carbon and nitrogen stocks presented in the results were based on the adjusted thickness of the soil depths. 


\subsection{Statistical Analyses}

Statistical differences were tested using univariate analysis of variance following the generalized linear model (GLM) procedure of SPSS version 17 for Windows (Julie, 2007). Differences were considered significant at the $P$ $<0.05$ level. Mean separations were done using Tukey's Honest Significance Difference (HSD) test for equal variances and Dunnet's test for not equal variances. The normality of the distribution of the data was analyzed using the Shapiro-Wilk normality test (Shapiro and Wilk, 1965). When the standard assumptions of normality were violated, non-parametric Kruskal-Wallis one-way ANOVA on ranks was used (Kruskal \& Wallis, 1952). The trend of bulk density, SOC and TN stocks with soil depth were subjected to regression to examine if there could be a linear trend. Correlation between SOC and TN stocks were examined for the different LULC types.

\section{Results and Discussions}

\subsection{Soil Organic Carbon (SOC) Stocks}

In the upper $0-10 \mathrm{~cm}$ soil depth, the SOC stock was significantly higher $(\mathrm{P}<0.05)$ in the NF than the MF, CAF and GL (Table 2; Figure 3). The loss of SOC from the surface soil following conversion of forest lands to agriculture was confirmed by several literature elsewhere in the world (Chan et al., 1995; Dalal\& Mayer, 1986; Davidson \& Ackerman, 1993; Demessie et al., 2013; Don et al., 2011; Assad et al., 2013; Campos et al., 2014; Lo Seen et al., 2010; Lozano-García and Parras-Alcántara, 2014; Wasak and Drewnik, 2015;Yu et al., 2014). In the $20-40 \mathrm{~cm}$ and $40-60 \mathrm{~cm}$ soil depths, SOC stocks in the GL were significantly higher than that found under the other LULC types (Table 2; Figure3). The significantly higher SOC stock in the two intermediate layers $(20-40 \mathrm{~cm}$ and 40-60 cm soil depths) under the GL than that found under the NF was also supported by previous studies (Assad et al., 2013; Braz et al., 2013). According to Russell (1960), conversion of native vegetation to long-term pastures has sometimes increased SOC levels particularly in the lower soil depths. This could be explained by the fast dynamics of long and fine roots in the GL (Shrestha \& Singh, 2008; Asaye \& Zewdie, 2013). In the 60-80cm and $80-100 \mathrm{~cm}$ soil depths, SOC stocks were not significantly different among the different LULC types (Table 2; Figure 3). When the top $1 \mathrm{~m}$ soil depth was considered, the SOC stocks were not significantly different among the different LULC types although the value for the MF was much lower (Table 2). Hence, our initial hypothesis of reduced SOC stocks in the overall $1 \mathrm{~m}$ soil depth after conversion of natural forest to agricultural land uses was partially rejected. This implies that, in a humid tropical system, the greater influence of land-use and land cover change from natural forest to well-managed agricultural land uses on SOC pools could be on the upper soil depths. This result is in agreement with a previous study by Schroth et al. (2002) who revealed lower SOC stocks in the top soils of the agricultural land uses as compared to the adjacent primary forests, but not when summed over the soil profile to $2 \mathrm{~m}$ depth. The significantly higher SOC stocks on the upper soil depths of natural forests as compared to agricultural land uses could be due to higher organic matter accumulation from the above ground biomass (litter fall), lower level of oxidation of organic matter, and the prevalence of water stable aggregates in the natural forest as compared to the agricultural land uses (Lemenih, 2004; Lemenih \& Itanna, 2004; ParrasAlcantara et al., 2015; Saha et al., 2011; 2014; Saikh et al., 1998). Changes in land use system may also alter soil microbial dynamics (Dinesh et al., 2004a, 2004b), which plays an instrumental role in either storing or loosing soil organic carbon (Sihi et al., 2016a), especially in the biologically active upper soil layer. However, our results contradict with the findings by Yimer et al. (2007) who reported significant decrease in SOC stocks in the entire $1 \mathrm{~m}$ soil depth of a cropland after 15 years since conversion from native forests. The lack of significant decrease in SOC stocks in the entire $1 \mathrm{~m}$ soil depth following conversion of montane forests to well-managed maize farm in this sub-humid area could be partly attributed to the improved land management practices encompassing retaining of crop residues and weeds to maintain the soil fertility of MF and application of ample nutrients in the form of chemical fertilizers which could enhance the biomass and thus the return to the soil in the form of crop residue. The lack of differences in SOC stock in the entire $1 \mathrm{~m}$ soil depth between the NF and the GL could also be attributed to the intercropping of legumes with grasses and absence of intensive grazing in the GL. The carbon sequestration potential of sub-humid areas is more than twice that of the semi-arid areas (Montagnini \& Nair, 2004). Although the effect of LULC changes on SOC stock of the entire $1 \mathrm{~m}$ soil depth could be low, the loss of organic carbon at ecosystem level could be still high due to the larger aboveground biomass in the dense natural forest ecosystems as compared to agricultural land uses.

The vertical distributions of SOC stocks were different among the forest and agricultural land use types. In the natural forest, the highest SOC stock (37\%) was observed in the top $0-10 \mathrm{~cm}$ soil depth which represents only $10 \%$ of the top $1 \mathrm{~m}$ depth. This could be attributed to the presence of organic horizon that encompasses the litter and humus layers in the upper soil depths of the natural forest. Moreover, the NF is not affected by human interventions in terms of harvesting of the crop biomass, weeding or tillage that all affect the SOC accumulation in the top soil depths of the agricultural land use types (Biazin et al., 2011; Hoogmoed, 1999). However, the SOC stocks below 
$10 \mathrm{~cm}$ soil depths were not significantly different in the NF (Table 2; Figure 3). The SOC stocks in the MF and GL increased from the surface until $40 \mathrm{~cm}$ soil depths and decreased below that (Table 2; Figure 3). The lower SOC stock in the surface as compared to the sub-surface layer of the MF might be attributable to the soil manipulation by tillage that would increase soil mixing between the surface $(0-10 \mathrm{~cm})$ and subsurface $(11-20 \mathrm{~cm})$ layers and oxidation of organic matter (Biazin et al., 2011; Gelaw et al., 2014). In the GL, the lower SOC stocks in the surface soil as compared to the depths below may be attributed to the addition of organic matter to the soil from numerous dead root biomass in the sub-surface layers (Asaye\&Zewdie, 2013). The effect of SOC stocks in the CAF were not significantly different among the different soil depths (Table 2; Figure 3). This could be associated with the effect of coffee-based agroforestry system in enhancing the soil organic carbon content due to the multi-purpose agroforestry tree species that have different rooting characteristics. Rasse et al. (2005) indicated the importance of root-derived soil organic carbon in land uses such as agroforestry systems. Agroforestry practices including the use of leguminous shade trees effectively maintained arbuscular mycorrhizal fungi numbers even in deeper soil depths compared with unshaded coffee plants (Muleta et al., 2008).

Table 2. SOC stocks $\left(\mathrm{Mg} \mathrm{ha}^{-1}\right)$, TN stocks $\left(\mathrm{Mgha}^{-1}\right)$ and soil $\mathrm{C}: \mathrm{N}$ ratio under different depths in the top $1 \mathrm{~m}$ soil depth of the different LULC types in Wondo Genet, Ethiopia

\begin{tabular}{|c|c|c|c|c|c|}
\hline \multirow[t]{2}{*}{ Parameters } & \multirow{2}{*}{$\begin{array}{l}\text { Soil depth } \\
(\mathrm{cm})\end{array}$} & \multicolumn{4}{|c|}{ Land uses } \\
\hline & & $N F$ & $M F$ & $C A F$ & $G L$ \\
\hline \multirow[t]{7}{*}{ Soil organic carbon } & $0-10$ & $54.46(8.8) b x$ & $14.56(0.9) \mathrm{ax}$ & 27.90(5.3)ax & 23.6(1.2)ax \\
\hline & $10-20$ & 23.33(3.9)ay & $15.84(1.1) \mathrm{ax}$ & $25.69(5.7) \mathrm{ax}$ & 21.3(1.2)axy \\
\hline & $20-40$ & 20.70(2.3)ay & 29.38(2.7)aby & 28.37(5.5)abx & $35.0(2.6) b y$ \\
\hline & $40-60$ & 17.27(3.5)ay & 21.21(1.8)abx & 24.67(4.8)abx & 28.4(3.1)bxy \\
\hline & $60-80$ & 15.62(3.5)ay & 19.64(2.1)ax & 23.73(5.1)ax & 24.2(3.8)axy \\
\hline & $80-100$ & 15.97(3.7)ay & $13.44(1.8) \mathrm{ax}$ & $14.65(2.6) a x$ & 20.0(3.0)ax \\
\hline & Total $1 \mathrm{~m}$ & $147.35(16.48) \mathrm{a}$ & $114.07(7.2) \mathrm{a}$ & $145.01(28.7) \mathrm{a}$ & $152.5(14.3) \mathrm{a}$ \\
\hline \multirow[t]{7}{*}{ Soil nitrogen } & $0-10$ & 3.35(0.6)by & $1.34(0.1) \mathrm{ax}$ & $1.42(0.3) \mathrm{ax}$ & $1.7(0.1) \mathrm{ax}$ \\
\hline & $10-20$ & $1.69(0.2) \mathrm{ax}$ & $1.33(0.1) a x$ & $1.28(0.1) \mathrm{ax}$ & $1.5(0.1) \mathrm{ax}$ \\
\hline & $20-40$ & $1.40(0.2) \mathrm{ax}$ & 2.06(0.2)aby & $1.62(0.2) \mathrm{ax}$ & $1.3(0.2) b y$ \\
\hline & $40-60$ & $1.25(0.2) \mathrm{ax}$ & $1.37(0.1) \mathrm{ax}$ & $1.27(0.2) \mathrm{ax}$ & $1.7(0.2) \mathrm{ax}$ \\
\hline & $60-80$ & $1.12(0.2) \mathrm{ax}$ & $1.31(0.1) \mathrm{ax}$ & $1.12(0.2) \mathrm{ax}$ & $1.4(0.1) \mathrm{ax}$ \\
\hline & $80-100$ & $1.02(0.1) a x$ & $1.15(0.1) a x$ & $0.90(0.1) a x$ & $1.3(0.1) a x$ \\
\hline & Total $1 \mathrm{~m}$ & $9.83(1.2) \mathrm{a}$ & $8.33(0.5) \mathrm{a}$ & $7.00(0.7) \mathrm{a}$ & $9.3(0.3) \mathrm{a}$ \\
\hline \multirow[t]{6}{*}{ Soil C:N } & $0-10$ & $14.1(1.7)^{\mathrm{ax}}$ & $10.9(0.3)^{b x}$ & $14.37475(0.57)^{\mathrm{ax}}$ & $14.02655(0.36)^{\mathrm{ax}}$ \\
\hline & $10-20$ & $13.4(1.4)^{\mathrm{ax}}$ & $11.9(0.4)^{\mathrm{ax}}$ & $14.48857(1.81)^{a x}$ & $14.63297(0.51)^{\mathrm{ax}}$ \\
\hline & $20-40$ & $14.8(0.5)^{a x}$ & $14.3(1.0)^{a x}$ & $15.86704(3.11)^{a x}$ & $15.94309(1.03)^{a x}$ \\
\hline & $40-60$ & $13.7(0.9)^{\mathrm{ax}}$ & $15.6(1.0)^{a x}$ & $15.32219(2.26)^{a x}$ & $17.15623(1.6)^{a x}$ \\
\hline & $60-80$ & $13.4(1.2)^{\mathrm{ax}}$ & $15.1(1.5)^{a x}$ & $16.61267(2.65)^{a x}$ & $15.19377(1.9)^{a x}$ \\
\hline & $80-100$ & $15.5(1.2)^{a x}$ & $10.0(1.1)^{a x}$ & $13.7(2.0)^{\mathrm{ax}}$ & $14.9(1.2)^{\mathrm{ax}}$ \\
\hline
\end{tabular}

Mean separation was done according to Tukey's mean significant test. Values in parentheses are standard error of the mean. Different letters $(\mathrm{a}-\mathrm{c})$ in the same row show significant difference $(\mathrm{P}<0.05)$ in SOC stocks, TN stocks and $\mathrm{C}: \mathrm{N}$ ratio among different LULC types and different letters $(\mathrm{x}-\mathrm{z})$ along the same column show significant difference $(\mathrm{P}<0.05)$ with depth for the same parameter.

\subsection{Total Nitrogen (TN) Stocks}

There was significantly higher $(\mathrm{P}<0.05) \mathrm{TN}$ stock $\left(3.35 \pm 0.55 \mathrm{Mg} \mathrm{ha}^{-1}\right)$ in the NF than the MF, CAF and GL $\left(1.34-1.68 \mathrm{Mg} \mathrm{ha}^{-1}\right)$ in the upper $0-10 \mathrm{~cm}$ soil depth (Table 2; Figure 4). The presence of higher TN stocks in the top $0-10 \mathrm{~cm}$ soil depth under the NF as compared to MF, CAF and GL was in line with previous studies in different agro-climatic conditions of Ethiopia (Lemenih \& Itanna, 2004; Yimer et al., 2007; Demessie et al., 2009). RoaFuentes et al. (2015) revealed that introduction of legumes in grazing grasslands that were converted from natural forests would restore the carbon and nitrogen status of the top soil layer. At the $20-40 \mathrm{~cm}$ soil depth, TN was significantly higher in the MF than that under the other LULC types (Table 2; Figure 4). This might be attributed to the leaching of nitrate fertilizer that is being applied in every growing season. At the $10-20 \mathrm{~cm}$ and below 40 $\mathrm{cm}$ soil depths, no significant differences were observed in TN stocks among the different LULC types. Similar to the SOC stocks, the TN stocks were not significantly different among the different LULC types when the top $1 \mathrm{~m}$ 
soil depth was considered (Table 2). The TN stocks in the MF increased from 0 to $40 \mathrm{~cm}$ soil depth having the highest values at the $20-40 \mathrm{~cm}$ soil depth and decreased from 40 to $100 \mathrm{~cm}$ soil depth (Table 2; Figure 4). In contrast, TN stocks in NF were significantly higher in $0-10 \mathrm{~cm}$ soil depth than the depths below (Table 2; Figure 4). This could be attributed to the presence of higher biomass added to the soil in the form of litter and the subsequent mineralization. Similar to the SOC stocks, the TN stocks in the CAF were not significantly different among the different soil depths (Table 2; Figure 4).

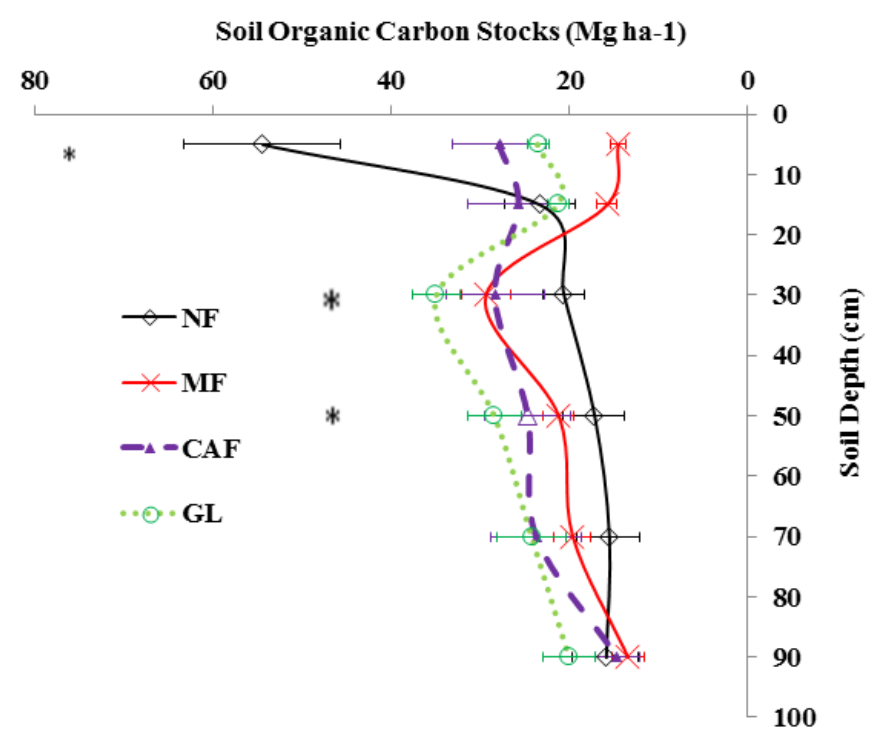

Figure 3. Soil organic carbon stocks $\left(\mathrm{Mg} \mathrm{ha}^{-1}\right)$ with soil depths $(0-100 \mathrm{~cm})$ under the natural forest (NF), maize field $(\mathrm{MF})$, coffee-based agroforestry $(\mathrm{CAF})$ and grass land $(\mathrm{GL})$. Error bars represent standard error of the mean $(n=5)$ for each LULC types.

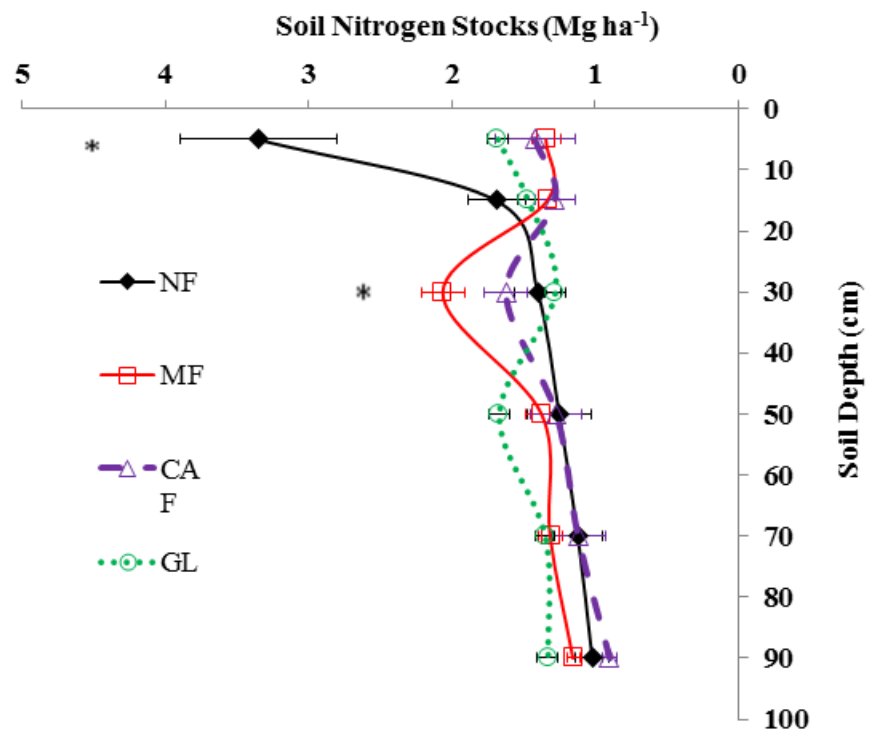

Figure 4. Total nitrogen stocks $\left(\mathrm{Mg} \mathrm{ha}^{-1}\right)$ with soil depth $(0-100 \mathrm{~cm})$ under the natural forest (NF), maize field $(\mathrm{MF})$, coffee-based agro-forestry (CAF) and grass land (GL). Error bars represent standard error of the mean $(n=5)$ for each LULC types. 


\section{$3.3 \mathrm{C}:$ N Ratio and Correlation of Carbon-Nitrogen Stocks}

In the upper $0-10 \mathrm{~cm}$ soil depth, the $\mathrm{C}: \mathrm{N}$ ratio was significantly lower under the MF than the other LULC types (Table 2; Figure 5). However, for the rest of the soil depths $(20-100 \mathrm{~cm})$, the $\mathrm{C}: \mathrm{N}$ ratio did not show any significant differences among the different LULC types. There was significant correlation $\left(R^{2}>0.5\right)$ between total Nitrogen (TN) Stocks and Soil Organic Carbon (Figure 6) and this correlation was higher $\left(R^{2}>0.89\right)$ under the NF as compared to the other agricultural land use types. The higher correlation between SOC and TN showed that the main source of total nitrogen is decomposition of organic matter. This has also been confirmed by other studies in tropical soils across various land uses and land cover types (Cleveland \& Liptzin, 2007; Yang, 2010). Therefore, TN could be explained as a linear function of the SOC stocks among the different LULC types (Figure6). The highest coefficient of determination $\left(\mathrm{R}^{2}=0.89\right)$ between the SOC and TN stocks was observed under the NF while the lowest $\left(\mathrm{R}^{2}=0.55\right)$ was observed under the MF.

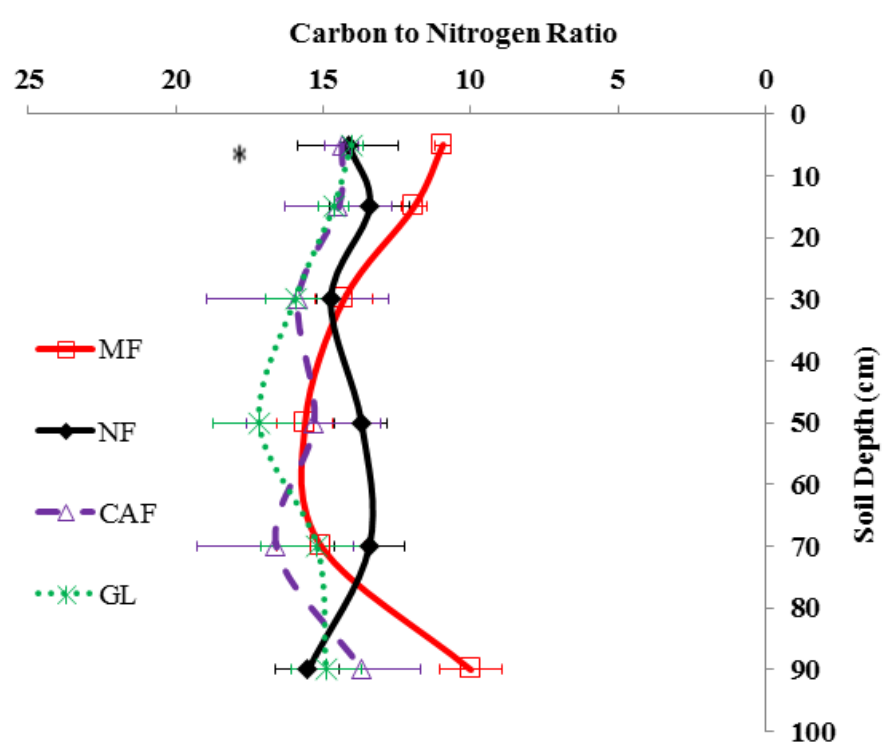

Figure 5. Soil carbon to nitrogen ratio in soil profile $(0-100 \mathrm{~cm})$ under the natural forest (NF), maize field $(\mathrm{MF})$, coffee-based agro-forestry (CAF) and grass land (GL). Error bars represent standard error of the mean $(n=5)$ for each LULC types

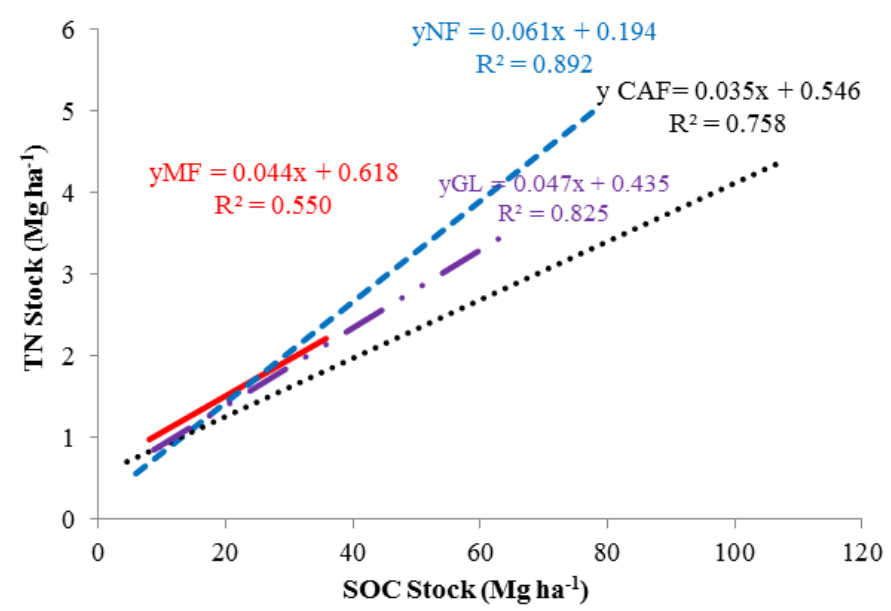

Figure 6. Total Nitrogen (TN) Stocks as a linear function of Soil Organic Carbon (SOC) stocks under natural forest (NF), Coffee-based Agroforestry (CAF), Grassland (GL), and Maize farm (MF) in Wondo genet, Southern Ethiopia 


\section{Conclusion}

There has been a persistent conversion of natural forests to agricultural land uses such as cultivated lands and grasslands in Africa during the last decades. This study revealed that, except for surface carbon and nitrogen pools, the effect of converting natural forest to well-managed agricultural land uses and agroforestry did not reduce the soil organic carbon and total nitrogen stocks in the total $1 \mathrm{~m}$ soil depth. However, there was a different pattern of soil organic carbon and total nitrogen distributions to the different soil depths among the different land use types. On the other hand, the correlation between the soil organic carbon and total nitrogen stocks was higher under the natural forest as compared to the other agricultural land use types. Overall, the results of this study suggest that indigenous tropical land use types such as crop cultivation, grazing grassland and agroforestry, if managed properly, may have minimum impact on the total soil organic carbon and total nitrogen stocks of the top $1 \mathrm{~m}$ soils. Improvements of natural grazing lands through over-sowing with herbaceous legumes, optimum application of chemical fertilizers and reduced removal of organic matter from crop fields can maintain the soil organic carbon and total nitrogen stocks.

\section{Acknowledgments}

The Sweden International Development Agency (SIDA) and Wondo Genet College of Forestry, Hawassa University of Ethiopia have financially supported this research. The authors would like to acknowledge Dr. Mulugeta Lemenih, Mr. Genene Assefa, Mr. Ashenafi Burka, the field assistants, laboratory technicians and farm managers at Wondo Genet College. The paper has been substantially improved upon the constructive comments of two anonymous reviewers and the editor. Mr. Amlaku Bikss is gratefully acknowledged for his language editorial support.

\section{References}

Albrecht, A., \& Kandji, S. T. (2003). Carbon sequestration in tropical agroforestry systems: a review. Agriculture, Ecosystems \& Environment, 99, 15-27. https://doi.org/10.1016/S0167-8809(03)00138-5

Asaye, Z., \& Zewdie, S. (2013). Fine root dynamics and soil carbon accretion under thinned and un-thinned Cupressus lusitanica stands in Southern Ethiopia. Plant \& Soil, 366, 261-271. https://doi.org/10.1007 /s11104-012-1420-3

Assad, E., Pinto, H., Martins, S., Groppo, J., Salgado, P., Evangelista, B., Vasconcellos, E., Sano, E., Pavão, E., Luna, R., Camargo, P., \& Martinelli, L. (2013). Changes in soil carbon stocks in Brazil due to land use: paired site comparisons and a regional pasture soil survey. Biogeosciences, 10, 6141-6160. https://doi.org/10.5194/ bg-10-6141-2013

Biazin, B., \& Sterk, G. (2013). Drought vulnerability drives land-use and land cover changes in the Rift Valley drylands of Ethiopia. Agriculture, Ecosystems \& Environment. 164, 100-113. https://doi.org/10.1016/j.agee. 2012.09.012

Biazin, B., Stroosnijder, L., Temesgen, M., Abdulkedir, A., \& Sterk, G. (2011). The effect of long-term Mareshaploughing on soil physical properties in the Central Rift Valley of Ethiopia. Soil \& Tillage Research, 111, 115-122. https://doi.org/ 10.1016/j.still.2010.09.006

Braz, S. P., Urquiaga, S., Alves, B. J. R., Jantalia, C. P., Guimarães, A. P., dos Santos, C. A., dos Santos, S. C., Pinheiro, E. F. M., \& Boddey, R. M. (2013). Soil carbon stocks under productive and degraded brachiaria pastures in the Brazilian Cerrado. Soil Science Society of America, 77, 914-928. https://doi.org/10.2136/ sssaj2012.0269

Bremner, J. M., \& Mulvaney, C. S. (1982). Nitrogen-total. In A. L., R. H. Miller, \& D. R. Keeney (Eds.), Methods of Soil Analysis (vol. 2, pp. 595-624). American Society of Agronomy, Madison, USA.

Bruun, T. B., Elberling, B., de Neergaard, A., \& Magid, J. (2015). Organic Carbon Dynamics in Different Soil Types After Conversion of Forest to Agriculture. Land Degradation \& Development, 26, 272 - 283. https://doi.org/10.1002/ldr.2205

Campos, A. C., Etchevers, J. B., Oleschko, K. L., \& Hidalgo, C. M. (2014). Soil microbial biomass and nitrogen mineralization rates along an altitudinal gradient on the cofre de perote volcano (Mexico): The importance of landscape position and land use. Land Degradation \& Development, 25, 581-593. https://doi.org/10.1002/ldr.2185

CSA (Central Statistical Authority). (2010). Agricultural sample survey 2009/2010: Report on area and production of crops. Addis Ababa, Ethiopia. Retrieved July 27, 2011, from http://www.csa.gov.et 
Chan, K. Y., Hodgson, A. S., \& Bowman, A. M. (1995). Degradation of Australian Vertisols after conversion from native grassland (Astreblalappacea) to continuous cropping in a semi-arid subtropical environment. Tropical Grasslands, 29, 210-217.

Cleveland, C. C., \& Liptzin, D. (2007). C:N:P Stoichiometry in soil: is there a "Redfield ratio" for the microbial biomass? Biogeochemistry, 85, 235-252. https://doi.org/10.1007/s10533-007-9132-0

Conant, R. T., Paustian, K., \& Elliot, E. T. (2001). Grassland management and conversion into grassland: effect on soil carbon. Ecological Applications, 11, 343-355. https://doi.org/10.1890/1051-0761

Dalal, R. C., \& Mayer, R. J. (1986). Long-term trends in fertility of soils under continuous cultivation and cereal cropping in southern Queensland: Total organic carbon and its rate of loss from the soil profile. Australian Journal of Soil Resources, 24, 281-292. https://doi.org/10.1071/SR9860281

Davidson, E. A., \& Ackerman, I. L. (1993). Changes in soil carbon inventories following cultivation of previously utilized soils. Biogeochemistry, 20, 161-193. https://doi.org/10.1007/BF00000786

de Souza, B. A. M., Fernandes, A. R., \& Alleoni, L. R. F. (2013). Soil attributes after the conversion from forest to pasture in Amazon. Land Degradation \& Development, 24, 33- 38. https://doi.org/10.1002/ldr.1100

Demessie, A. (2009). Effect of conversion of natural forest to plantations, traditional agroforestry andcultivated lands on carbon sequestration and maintenance of soil quality in Gambo District, Southern Ethiopia. Ph.D thesis, Norwegian University of Life Sciences, Norway.

Demessie, A., Singh, B. R., \& Lal, R. (2013). Soil carbon and nitrogen stocks under chronosequence of farm and traditional agroforestry land uses in Gambo District, Southern Ethiopia. Nutrient Cycling in Agroecosystem, 95, 365-375.

Dessie, G., \& Kleman, J. (2007). Pattern and magnitude of deforestation in the south Central Rift Valley region of Ethiopia. Mountain Research \& Development, 27, 162-168. http://dx.doi.org/10.1659/mrd.0730

Dinesh, R., Chaudhuri, S. G., Ganeshamurthy, A. N., \& Pramanik, S. C. (2004a). Biochemical properties of soils of undisturbed and disturbed mangrove forests of South Andaman (India). Wetlands Ecology and Management, 12(5), 309-320.

Dinesh, R., Ghoshal, C. S., \& Sheeja, T. E. (2004b). Soil biochemical and microbial indices in wet tropical forests: Effects of deforestation and cultivation. Journal of Plant Nutrition and Soil Science, 167(1), 24-32.

Don, A., Schumacher, J., \& Freibauer, A. (2011). Impact of tropical land-use change on soil organic carbon stocks - a meta-analysis. Global Change Biology, 17, 1658-1670. https://doi.org/10.1111/j.1365-2486.2010.02336.x

FAO. (2010). Global Forest Resources Assessment 2010 - Country Report Ethiopia. Food and Agriculture Organization (FAO), Rome, Italy. Retrieved September 15, 2012 from www. fao.org/forestry/fra/fra2010/en

FAO. (1988). FAO/UNESCO Soil Map of the World: Revised legend, with corrections and updates. World Soil Resources Report 60. Food and Agricultural Organization of the United Nations, Rome.

FAO. (1986). Highland reclamation study: Ethiopia. Final report, Vols. 1\&2. Food and Agricultural Organization of the United Nations, Rome, Italy,

Garedew, E., Sandewall, M., Soderberg, U., \& Campbell, B. M. (2009). Land use and land-cover dynamics in the Central Rift Valley of Ethiopia. Environmental Management, 44, 683-694. https://doi.org/10.1007/s00267009-9355-z

Gebrehiwot, S. G., Ayele, T., \& Bishop, K. (2010). Forest cover and stream flow in a headwater of the Blue Nile: Complementing observational data analysis with community perception. AMBIO, 39, 284-294. https://doi.org/ 10.1007/s13280-010-0047-y

Gelaw, A. M., Singh, B. R., \& Lal, R. (2014). Organic carbon and nitrogen associated with soil aggregates and particle sizes under different land uses in Tigray, Northern Ethiopia. Land Degradation \& Development, 26, 690-700. https://doi.org/10. 1002/ldr. 2261

Grossman, R. B., \& Reinsch, T. G. (2002). Bulk density and linear extensibility, in: Methods of Soil Analysis, Part 4: Physical Methods, edited by: Dane, J. H. and Topp, G. C. Soil Science Society of America, Book Series No. 5, Madison, WI, USA, pp 201-228.

Guo, L., \& Gifford, R. (2002). Soil carbon stocks and land use change: a Meta analysis. Global Change Biology, 8, 345-360. https://doi.org/10.1046/j.1354-1013.2002.00486.x 
Hoogmoed, W. B. (1999). Tillage for soil and water conservation in the semi-arid tropics. Doctoral Thesis. Wageningen Agricultural University, p. 184.

Julie, P. (2007). SPSS survival manual: A step by step guide to data analysis using SPSS for Windows Version 15. 3rd edition. Open University Press, UK.

Kalema, V. N., Witkowski, E. T. F., Erasmus, B. F. N., \& Mwavu, E. N. (2014). The impacts of changes in land use on woodlands in an equatorial African Savanna. Land Degradation \& Development, 7, 632-641. https://doi.org/10.1002/ldr.2279

König, H. J., Zhen, L., Helming, K., Uthes, S., Yang, L., Cao, X., \& Wiggering, H. (2014). Assessing the impact of the sloping land conversion program on rural sustainability in Guyuan, Western China. Land Degradation \& Development, 25, 385-396. https://doi.org/10.1002/ldr.2164

Kruskal, W., \& Wallis, W. (1952). Use of ranks in one-criterion variance analysis. Journal of American Statistics Associations, 47, 583-621.

Lambin, E. F., Geist, H. J., \& Lepers, E. (2003). Dynamics of land-use and land-cover change in tropical regions. Annu. Rev. Environ. Resources, 28, 205-41. https://doi.org/10.1146/annurev.energy.28.050302.105459

Lemenih, M. (2004). Effects of Land Use Changes on Soil Quality and Native Flora Degradation and Restoration in the Highlands of Ethiopia. Doctoral Thesis Swedish University of Agricultural Sciences Uppsala, Sweden.

Lemenih, M., \& Itanna, F. (2004). Soil carbon stocks and turnovers in various vegetation types and arable lands along an elevation gradient in southern Ethiopia. Geoderma, 123, 177-188. https://doi.org/10.1016/ j.geoderma.2004.02.004

Lo Seen, D., Ramesh, B. R., Nair, K. M., Martin, M., Arrouays, D., \& Bourgeon, G. (2010). Soil carbon stocks, deforestation and land-cover changes in the Western Ghats biodiversity hotspot (India). Global Change Biology, 16(6), 1777-1792

Lozano-García, B., \& Parras-Alcántara, L. (2014). Variation in soil organic carbon and nitrogen stocks along a topo-sequence in a traditional Mediterranean olive grove. Land Degradation \& Development, 25, 297-304. https://doi.org/10.1002/ldr. 2284

Malhi, Y., Baldocchi, D. D., \& Jarvis, P. J. (1999). The carbon balance of tropical, temperate and boreal forests. Plant, Cell \& Environment, 22, 715-740. https://doi.org/10.1046/j.1365-3040.1999.00453.x

McLauchlan, K. K., Hobbie, S. E., \& Post, W. M. (2006). Conversion from agriculture to grassland builds soil organic matter on decadal timescales. Ecological Applications, 16, 143-153. https://doi.org/10.1890/04-1650

Meersmans, J., van Wesemael, B., De Ridder, F., Fallas, D. M., De Baets, S., \& Van Molle, M. (2009). Changes in organic carbon distribution with depth in agricultural soils in Northern Belgium, 1960-2006. Global Change Biology, 15, 2739-2750. https://doi.org/10.1111/j.1365-2486.2009.01855.x

Mendham, D., Sankaran, K., O'connell, A., \& Grove, T. (2002). Eucalyptus globulus harvest residue management effects on soil carbon and microbial biomass at 1 and 5 years after plantation establishment. Soil Biol. Biochemistry, 34, 1903-1912.https://doi.org/10.1016/S0038-0717(02)00205-5

MEA (Millennium Ecosystem Assessment). (2005). Ecosystems and human well-being: Current states and trends. Washington, DC. pp 625.

Moges, A., \& Holden, N. M. (2009). Land cover change and gully development between 1965 and 2000 in Umbulo catchment, Ethiopia. Mountain Research \& Development, 29, 265-276. https://doi.org//10.1659/mrd.00015

Mohawesh, Y., Taimeh, A., \& Ziadat, F. (2015). Effects of land use changes and soil conservation intervention on soil properties as indicators for land degradation under a Mediterranean climate. Solid Earth, 6, 857-868. https://doi.org/10. 5194/se-6-857-2015

Montagnini, F., \& Nair, P. K. R. (2004). Carbon sequestration: An underexploited environmental benefit of agroforestry systems. Agroforestry Systems, 61, 281-295.

Muleta, D., Assefa, F., Nemomissa, S., \& Granhall, U. (2008). istribution of arbuscular mycorrhizal fungi spores in soils of smallholder agroforestry and monocultural coffee systems in southwestern Ethiopia. Biology and Fertility of Soils, 44, 653-659. https://doi.org/10.1007/s00374-007-0261-3

Murty, D., Kirschbaum, M. U. F., McMurtrie, R. E., \& Mc Gilvray, H. (2002). Does conversion of forest to agricultural land change soil carbon and nitrogen? a review of the literature. Global Change Biology, 8, 105123. https://doi.org/10.1046/j.1354-1013.2001.00459.x 
Parras-Alcantara, L., Lozano-Garcia, B., Brevik, E. C., \& Cerda, A. (2015). Soil organic carbon stocks assessment in Mediterranean natural areas: A comparison of entire soil profiles and soil control sections. Journal of Environmental Management, 155, 219-228. https://doi.org/10.1016/j.jenvman.2015.03.039

Parras-Alcántara, L., Martín-Carrillo, M., \& Lozano-García, B. (2013). Impacts of land use change in soil carbon and nitrogen in a Mediterranean agricultural area (Southern Spain). Solid Earth, 4, 167-177. https://doi.org/10.5194/se-4-167-2013

Post, E., Forchhammer, M. C., Bret-Harte, M. S., Callaghan, T. V., Christensen, T. R., Elberling, B., ... Aastrup, P. (2009). Ecological dynamics across the arctic associated with recent climate change. Science, 325, 13551358. https://doi.org/10.1126/science. 1173113

Rasse, D. P., Rumpel, C., \& Dignac, M. F. (2005). Is soil carbon mostly root carbon? Mechanisms for a specific stabilization. Plant Soil, 269, 341-356. https://doi.org/10.1007/s11104-004-0907-y

Reusing, M. (2000). Change detection of natural high forests in Ethiopia using remote sensing and GIS techniques. International Archives of Photogrammetry and Remote Sensing, Amsterdam, the Netherlands.

Roa-Fuentes, L. L., Martínez-Garza, C., Etchevers, J., \& Campo, J. (2015). Recovery of coil C and N in a tropical pasture: Passive and active restoration. Land Degradation \& Development, 26, 201-210. https://doi.org/10. 1002/ldr. 2197

Russell, J. S. (1960). Soil fertility changes in the long-term experimental plots at Kybybolite, South Australia. I. Changes in $\mathrm{pH}$, total nitrogen, organic carbon, and bulk Density. Australian Journal of Agricultural Research, 11, 902-926. https://doi.org/10.1071/AR9600902.

Saha, D., Kukal, S. S., \& Sharma, S. (2011). Land use impacts on SOC fractions and aggregate stability in typicustochrepts of Northwest India. Plant and Soil, 339(1), 457-470.

Saikh, H., Varadachari, C., \& Ghosh, K., (1998). Changes in carbon, nitrogen and phosphorus levels due to deforestation and cultivation: a case study in Simlipal National Park, India. Plant Soil, 198, 137-145.

Schnitzer, M. (1982). Total carbon, organic matter, and carbon, In A. L. Page, R. H. Miller, \& D. R. Keeney (Eds.), Methods of Soil Analysis (Part 2, 2nd Ed., pp. 539-577). Agronomy Monograph, vol. 9. American Society of Agronomy, Madison, WI.

Shapiro, S. S., \& Wilk, M. B. (1965). An analysis of variance test for normality (complete samples). Biometrika, 52, 591-611. https://doi.org/10.2307/2333709

Shrestha, B. M., \& Singh, B. R. (2008). Soil and vegetation carbon pools in a mountainous watershed of Nepal. Nutrient Cycling in Agroecosystems, 81, 179-191.

Sihi, D. (2017a). Evaluation of soil health in organic vs. conventional farming of basmati rice in North India. Journal of Plant Nutrition and Soil Science, 180(3), 389-406.

Sihi, D., Inglett, P. W., Gerber, S., \& Inglett, K. S. (2017b). Rate of warming affects temperature sensitivity of anaerobic peat decomposition and greenhouse gas production. Global Change, Biology, n/a-n/a.

Sihi, D., Gerber, S., Inglett, P. W., \& Inglett, K. S. (2016a). Comparing models of microbial-substrate interactions and their response to warming. Biogeosciences, 13(6), 1733-1752.

Sihi, D., Inglett, P. W., \& Inglett, K. S. (2016b). Carbon quality and nutrient status drive the temperature sensitivity of organic matter decomposition in subtropical peat soils. Biogeochemistry, 131, 103-119.

Solomon, D., Fritzsche, F., Lehmann, J., Tekalign, M., \& Zech, W. (2002). Soil organic matter dynamics in the sub-humid agro-ecosystems of the Ethiopian highlands: Evidence from natural $13 \mathrm{C}$ abundance and particlesize fractionation. Soil Science Society of America Journal, 66, 969-978. https://doi.org/10.2136/sssaj 2002.9690

Tadesse, G. (2001). Land Degradation: A challenge to Ethiopia. Environmental Management, 27, 815-824. https://doi.org/10.1007/s002670010190

Teklay, T. (2004). Seasonal dynamics in the concentrations of macronutrients and organic constituents in green and senesced leaves of three agroforestry species in southern Ethiopia. Plant \& Soil, 267, 297-307. https://doi.org/10.1007/s11104-005-0124-3

Teklay, T., \& Malmer, A. (2004). Decomposition of leaves from two indigenous trees of contrasting qualities under shaded-coffee and agricultural land-uses during the dry season at Wondo Genet, Ethiopia. Soil Biology \& Biochemistry, 36, 777-786. https://doi.org/10.1016/j.soilbio.2003.12.013 
Wasak, K., \& Drewnik, M. (2015). Land use effects on soil organic carbon sequestration in calcareous Leptosols in former pastureland - a case study from the Tatra Mountains (Poland). Solid Earth, 6, 1103-1115. https://doi.org/10.5194/se-6-1103-2015

Wolka, K., Tadesse, T., Garedew, E., \& Yimer, F. (2015). Soil erosion risk assessment in the Chaleleka wetland watershed, Central Rift Valley of Ethiopia. Environmental Systems Research, 4, 1-12. https://doi.org/ 10.1186/s40068-015-0030-5

Yang, Y. H., Fang, J. Y., Guo, D. L., Ji, C. J., \& Ma, W. H. (2010). Vertical patterns of soil carbon, nitrogen and carbon: nitrogen stoichiometry in Tibetan grasslands. Biogeosciences Discussions, 7, 1-24. https://doi.org/10. 5194/bgd-7-1-2010

Yimer, F. (2002). Soils of the Lango sub-catchment: Their status and potentials. Wondo Genet College of Forestry, Wondo Genet.

Yimer, F., Ledin, S., \& Abdelkadir, A. (2007). Changes in soil carbon and total nitrogen stocks in three adjacent land-use types in the Bale Mountains, South-eastern highlands of Ethiopia. Forest Ecology \& Management, 242, 337-342. https://doi.org/10.1016/j.foreco.2007.01.087

Yu, B., Stott, P., Di, X. Y., \& Yu, H. X. (2014). Assessment of land cover changes and their effect on soil organic carbon and soil total nitrogen in daqing prefecture, China. Land Degradation \& Development, 25, 520-531. https://doi.org/10. 1002/ldr. 2169

Yu, Y., Wei, W., Chen, L. D., Jia, F. Y., Yang, L., Zhang, H. D., \& Feng, T. J. (2015). Responses of vertical soil moisture to rainfall pulses and land uses in a typical loess hilly area, China. Solid Earth, 6, 595-608. https://doi.org/10. 5194/se-6-595-2015

Yu, Y., Wei, W., Chen, L. D., Jia, F. Y., Yang, L., Zhang, H. D., \& Feng, T. J. (2015). Responses of vertical soil moisture to rainfall pulses and land uses in a typical loess hilly area, China. Solid Earth, 6, 595-608. https://doi.org/10. 5194/se-6-595-2015

Zeleke, G., \& Hurni, H. (2001). Implications of land use and land cover dynamics for Mountain resource degradation in the Northwestern Ethiopian Highlands. Mountain Research \& Development, $21,184-191$. https://doi.org/10.1659/0276-4741

\section{Copyrights}

Copyright for this article is retained by the author(s), with first publication rights granted to the journal.

This is an open-access article distributed under the terms and conditions of the Creative Commons Attribution license (http://creativecommons.org/licenses/by/4.0/). 